\title{
Ofelie wiecznie żywe, czyli literatura w fotografii (infrazy czeskie)
}

\section{The Ever-living Ophelias - Literature in Photography (the Czech Inphrases)}

\begin{abstract}
The article describes examples of inphrases whose purpose is to arouse emotions evoked through the reading of a literary text and to recreate those emotions in an artwork, in this case, in the works of three Czech photographers. The starting point for the analysis of the three selected photographs is, first and foremost, the character of Ophelia from William Shakespeare's Hamlet, and the description of her tragic death. This description is subsequently set against a painting titled Ophelia, created by a Pre-Raphaelite artist, John Everett Millais. Further analysis focuses on the photographs by Martin Faltejsek (the Weightless series), Jan Faukner (the Nemesis series), and Barbora Bálková (the Literary suicides series). The analysis of the photographs which represent Ophelia concerns, among others, their symbolism (femininity, water, nature archetypes), and highlights the similarities and differences between the three media, i.e. literature, painting, and photography. Apart from covering the issues of visual experience, the article addresses the question of whether the particular photographs escape the Shakespearian context and fit within the fine-art context, as well as whether the artists propose their own, new reading of the myth of Ophelia.
\end{abstract}

Keywords: photography, novel, inphrasis, literature, Czech photography

Spotkanie słowa i obrazu wielokrotnie opisywane było z punktu widzenia ekfraz artystycznych, których celem stało się przede wszystkim wywołanie uniwersalnej emocji wynikającej z kontemplacji dzieła sztuki. Takie interferencje często związane są z ekfrazą literacką, co oznacza, że w warstwie narracyjnej odnaleźć można na przykład opis dzieła sztuki lub innego rodzaju odniesienie do konkretnego obiektu twórczości artystycznej. Inaczej jest w przypadku infrazy, której zadanie to zobrazowanie emocji wzbudzonych przez dzieło literackie. Teresa Radziewicz pisze o rozwoju tych dwóch pojęć następująco: “[...] o ile [...] od czasu powstania ekfraz do momentu ich wyodrębnienia i nazwania upłynęło w przybliżeniu tysiąc lat, o tyle pojęcie infrazy kształtuje się niejako hic et nunc, na naszych oczach. Prawdopodobnie rozwój tego zjawiska wiąże się z intensyfika- 
cją fenomenu przenikania się sztuk oraz z ekspresją szeroko rozumianej kultury obrazkowej i jest swego rodzaju jej uszlachetnieniem"1. Niniejszy tekst będzie się zatem odnosił właśnie do zjawiska infrazy, czyli odbicia literatury w czeskiej fotografii artystycznej. Owe literackie ślady zawężone zostaną do postaci Ofelii, bohaterki tragedii Williama Szekspira Hamlet.

\section{Źródła inspiracji}

Nim przejdziemy do interpretacji tytułowych infraz, przyjrzyjmy dwóm źródłom, które zainspirowały czeskich artystów. Szekspir, ustami Królowej, następująco opisuje śmierć Ofelii:

Owdzie nad potokiem stoi

Pochyła wierzba, której siwe liście

W lustrze się czystej przeglądają wody.

Tam ona wiła fantastyczne wieńce

Z pokrzyw, stokrotek, jaskrów i podłużnych

Karmazynowych kwiatów, którym nasi

Sprośni pasterze szpetną dają nazwę,

A zaś dziewice w skromności je zowią

Palcami zmarłych. Otóż chcąc zawiesić

Jeden z tych wianków na zwisłej gałęzi,

Nie dość ostrożnie wspięła się na drzewo.

Złośliwa gałąź złamała się pod nią.

I z kwiecistymi trofeami swymi

Wpadło w toń biedne dziewczę. Przez czas jakiś

Wzdęta sukienka niosła ją po wierzchu

Jak nimfę wodną i wtedy, nieboga,

Jakby nie znając swego położenia

Lub jakby czuła się w swoim żywiole,

Śpiewała starych piosenek urywki,

Ale niedługo to trwało, bo wkrótce

Nasiąkłe szaty pociągnęły z sobą

Biedną ofiarę ze sfer melodyjnych

W zimny muł śmierci².

1. Teresa Radziewicz, “Od ekfrazy do infrazy”, w: Logos - filozofia słowa. Szkice opograniczach języka, filozofii i literatury, red. Krzysztof Andruczyk, Ewa Gorlewska, Krzysztof Korotkich (Białystok: Instytut Filologii Polskiej, Wydział Filologiczny Uniwersytetu w Białymstoku, 2017, 167, http:/repozytorium.uwb. edu.pl/jspui/bitstream/11320/8099/1/T_Radziewicz_Od_ekfrazy_do_infazy.pdf(20.12.2019).

2. William Shakespeare, Hamlet, przeł. Józef Paszkowski (Warszawa: Państwowy Instytut Wydawniczy, 1973), 107: http:/wolnelektury.pl/media/book/pdf/hamlet.pdf (20.12.2019). 
Na obrazie Johna Everetta Millais’a widzimy zaś młodą dziewczynę unoszoną przez nurt rzeki. Ma ona otwarte oczy i nieznacznie rozchylone usta. Jej ręce są sztywno zgięte w łokciach, a otwarte dłonie kieruje ku górze; są one jakby zastygłe w geście dziękczynienia lub przyjmowania błogosławieństwa. Ich otwartość podkreśla, że Ofelia nie ma nic do ukrycia, całkowicie i świadomie oddaje się temu, co za chwilę nastąpi. W prawej ręce trzyma bukiet kwiatów. Postać obserwujemy z prawej strony. W drugim planie można zauważyć pochyłą wierzbę, tę, którą opisał Szekspir. "Wierzbę od dawien dawna uważano za roślinę miłującą życie [...]" pisze w Świecie symboliki chrześcijańskiej Dorothea Forstner³. Badaczka dalej dodaje: "[...] w języku łacińskim nazywano ją salix (od salire - skakać)"4, co może być świadomym zamysłem Szekspira, chcącego podkreślić motyw samobójstwa Ofelii. Ponadto wierzba symbolizuje czystość oraz łączy się z symboliką duchową i ponadnaturalną̧. Postać dziewczyny zdaje się swobodnie łączyć z tą symboliką, z naturą, z wodną roślinnością, Ofelia jest jej częścią. Na obrazie dominuje archetypowy żywioł wody połączony z żywiołem kobiecości. Oś obrazu jest horyzontalna, wyznaczona przez widoczną linię brzegu i roślinność, która tworzy coś na kształt ramy.

\section{Ofelia popkulturowa}

Ta Szekspirowska postać kobieca jest jedną z bardziej znanych bohaterek literackich, której symboliczne znaczenie wyszło poza swoje pierwotne ramy. Ofelia stała się swego rodzaju uniwersalnym toposem ewoluującym za sprawą kolejnego twórcy - Johna Everetta Millais’a i jego obrazu zatytułowanego Ofelia. Millais stworzył kolejny topos, tym razem ikonograficzny, i to właśnie ta postać wizualna, nadana Ofelii przez artystę wywodzącego się z grupy prerafaelitów, przeniknęła do powszechnej świadomości kulturowej.

Ofelia Szekspira to literackie wyobrażenie odrzucenia, samotności i braku samodzielności. Postać ta reprezentuje antynomie miłości i śmierci oraz ścisłą symbiozę między kobiecością a naturą. Przywołanie jej imienia nieodłącznie przywodzi na myśl symbolikę wody, tajemnicy i obłędu. Zatrzymana w wiecznej pozie śmierci na obrazie Millais’a, w późniejszych artystycznych i literackich wyobrażeniach często wymyka się tekstualnemu wyobrażeniu. Anne Cousseau w artykule "Ophélie: histoire d'un mythe fin de siècle" charakteryzuje tę postać następująco: “[...] Historia Ofelii jest historią podmiotu, którego nie można

3. Dorothea Forstner, Świat symboliki chrześcijańskiej, przeł. Wanda Zakrzewska, Paweł Pachciarek i Ryszard Turzyński (Warszawa: Instytut Wydawniczy Pax, 1990), 178.

4. Forstner, Świat symboliki..., 178.

5. Forstner, Świat symboliki..., 179. 
ukonstytuować, który wymyka się wszelkiej samoświadomości i jest budowany jedynie w spojrzeniu i dyskursie Innego". Takie właśnie spojrzenia zewnętrzne kształtują tę postać jako swego rodzaju wielokrotną transmutację mitu. O dużym zainteresowaniu, jakim cieszy się omawiana postać wśród badaczy i artystów, świadczą liczne odniesienia naukowe i kulturowe. W Internecie można natknąć się na rozbudowane bibliografie prac naukowych dotyczących tej bohaterki ${ }^{7}$. Interesująca jest na przykład strona przedstawiająca zebrane materiały, w których Ofelia jawi się jako ikona popkultury. Mamy tu nie tylko eseje naukowe, lecz także liczne odwołania do sztuk wizualnych, literatury pięknej, teorii kryminalnych dotyczących śmierci Ofelii i przykłady komercjalizacji jej imienia (autor strony podaje przykład bloga, na którym przywołuje się obraz Millais’a, jednak w jego blogowej wersji kobieta trzyma w jednej ręce butelkę wina, w drugiej zaś kieliszek, a pod spodem znajduje się hasło reklamowe: Szalona kobieta zakochana $w$ winie ${ }^{8}$ ). Imię Ofelii było również inspiracją dla konkretnych typów sukienek, bielizny czy, co dość zaskakujące, sukien ślubnych. Natomiast japońska marka modowa Miharajasuhiro stworzyła w roku 2011 instalację artystyczną bezpośrednio odnoszącą się do wspomnianego wcześniej obrazu w celu przedstawienia elementów swojej najnowszej kolekcji. Jeśli chodzi o literaturę popularną, to czeska pisarka Susanna Kubelka wydała w roku 2015 powieść pod znamiennym tytułem Ofelia uczy się pływać. Ostatnim z przywołanych tu przykładów popkulturowego życia Szekspirowskiej Ofelii może być teledysk do piosenki Nicka Cave’a i Kylie Minogue Where the Wild Roses Grow, w którym australijska piosenkarka unosi się na wodzie jako Ofelia.

\section{Ofelia w fotografii światowej}

Niewątpliwie jedne z ciekawszych odniesień do postaci Ofelii odnaleźć można w fotografii. Zdjęcia stają się wówczas odzwierciedleniem rzeczywistości narracyjnej, choć tak naprawdę dalej odnoszą się do jej malarskiego wyobrażenia. W tym wypadku należy mówić o swoistym potrójnym kodowaniu, kiedy to obraz fotograficzny korzysta i inspiruje się dwoma źródłami - literackim i artystycznym, jednak struktura symboliczna zdjęcia zawsze odnosi się w pierwszej kolejności

6. Anne Cousseau, “Ophélie: histoire d'un mythe fin de siècle”, w: Revue d'histoire littéraire de la France Vol. 101, 1/2001, 101-122, http://www.cairn.info/revue-d-histoire-litteraire-de-lafrance-2001-1-page-105.htm (20.12.2019).

7. Np. strona: http://www.hamlethaven.com/ophelia.html (20.12.2019).

8. Zob. http://sites.google.com/site/opheliaandpopularculture/home/the-name-ophelia-and-its-commercialization (20.12.2019).

9. Zob. http://stylebubble.co.uk/style_bubble/2011/10/ophelias-dream.html (20.12.2019). 
do prawzoru, czyli tekstu. Tworzy się wówczas coś na wzór palimpsestu kulturowego, którego intersemiotyczny charakter wyraża daną strategię artystyczną.

Dekonstrukcją mitu Ofelii zajmowali się między innymi tacy artyści fotograficy jak na przykład Alessandra Sanguinetti (Ophelias z cyklu The Adventures of Guille and Belinda and The Enigmatic Meaning of Their Dreams), Tom Hunter (The Way Home z cyklu Life and Death in Hackney), Gregory Crewdson (fotografia bez tytułu z cyklu Twilight) czy Helen van Meere, której prace można było oglądać na wystawie Ik, Ofelia (Me, Ophelia). Wystawa ta odbyła się w Amsterdamie w Muzeum Van Gogha w dniach 15.02.-18.05. 2008 roku. Przedstawione tam fotografie 30 artystów miały nawiązywać do obrazu Millais’a. Twórcy skupili się na reinterpretacji wątku Ofelii w dwóch przełomowych momentach jej historii: momentu tuż przed śmiercią i już po niej (łącznie z wyobrażeniem wyłowienia ciała i szykowania go do pogrzebu) ${ }^{10}$. Interesującym przedsięwzięciem artystycznym i reinterpretacyjnym jest utworzony na stronie www.fotocomunity.de profil dotyczący postaci Ofelii, na którym umieszczane są amatorskie fotografie autorów zainspirowanych obrazem i tekstem ${ }^{11}$.

Również wśród prac czeskich artystów odnaleźć można liczne wątki nawiązujące do tej tragicznej postaci kobiecej.

\section{Reinscenizacje czeskie - Martin Faltejsek i Jan Faukner}

Fotografie czeskich artystów, których analizy zostaną przedstawione w kolejnej części artykułu (będą to: Martin Faltejsek, Jan Faukner i Barbora Bálková), w większym bądź mniejszym stopniu nawiązują do obu wspomnianych wyżej (literackiej i malarskiej) wizji śmierci Ofelii. Zawsze jednak tekst i obraz są osią tematyczną, wokół której krążą ich prace.

Wśród współczesnych czeskich twórców fotografii artystycznej na uwagę zasługuje przedstawiciel najmłodszego pokolenia Martin Faltejsek (1993). Urodzony w miasteczku Lanškroun, żyje i pracuje w Pradze, natomiast studiuje w Instytucie Twórczej Fotografii w Uniwersytecie Śląskim w Opawie. Faltejsek jest trzykrotnym laureatem konkursu Czech Press Photo. Za swoją twórczość artystyczną zdobył również nominację do nagrody World Press Photo. Jest autorem przede wszystkim autoportretów, których główną ideą jest namysł nad poczuciem własnej tożsamości i pojęciem domu - tego fizycznego i mentalnego.

Interesującym, z punktu widzenia niniejszego tekstu, jest cykl fotografii wykonanych w latach 2013-2017, zatytułowany Weightless, a zwłaszcza jedno zdjęcie

10. Amatorski filmik $\mathrm{z}$ otwarcia wystawy można obejrzeć pod tym adresem: http://www. youtube.com/watch?v=Mp7boH9izn8 (20.12.2019).

11. Zob. http://www.fotocommunity.de/photos/ophelia (20.12.2019). 
(bez tytułu) nawiązujące do postaci i przedstawień Ofelii. Faltejsek akcentuje to, iż cały cykl autoportretów jest odą do przyrody, do lasów, bagien i stawów jego rodzinnych okolic. Odą do miejsc, w których artysta czuje się wolny i może się wtopić w otoczenie i przyrodę. Podkreśla, że projekt Weightless pozwolił mu zatrzymać się i na chwilę wysiąść z karuzeli życia. Cykl jest wyrazem poszukiwania własnej tożsamości, a przede wszystkim odzwierciedla stosunek autora do przyrody Pogórza Orlickiego ${ }^{12}$.

We wszystkich fotografiach tej serii dominuje żywioł dzikiej natury, połączenie motywów wody i lasu. Woda symbolizuje między innymi upływ czasu, podświadomość i śmierć. W przypadku zdjęć Faltejska jest to woda stojąca, a więc powiązana ze zmianą, ale zmianą dotyczącą nie jej samej, a tego, który jest w niej zanurzony. Zdeňka Kalnická pisze, iż w takim przypadku (woda stojąca, przedstawienie jeziora lub stawu) podkreślony zostaje czas, który nie upływa, stoi w miejscu, natomiast zmieniamy się my sami. Zanurzenie w takiej wodzie jest "chwilą oznaczającą wieczność, jest to śmierć nie symbolizująca jednak końca drogi, którą zmierza nasze życie, jest to ciągła obecność czegoś wyższego, transcendentnego"13. Dla Faltejska żywioł wody jest równie ważny i symboliczny, fotograf często podkreśla, że pracuje wszędzie tam, gdzie płynie woda. Symbolika wody zdaje się łączyć u niego z poszukiwaniem własnej tożsamości, łączy się ze swoistym stanem liminalnym, w którym przebywa artysta, stanem między tam i tu, kiedyś i teraz. Z taką właśnie granicznością wiąże się jego zdjęcie będące odniesieniem do kompozycji Millais’a i tekstu Szekspira.

Fotografia, o której mowa, nie łączy się z archetypowym żywiołem kobiecości; odwrotnie - wyraża doświadczenie męskości. Ofelię reprezentuje w tym przypadku sam Faltejsek. Jego ciało spokojnie unosi się na wodzie, jego oczy są zamknięte a twarz łagodna, maluje się na niej odprężenie, brakuje tego wyrazu szaleństwa widocznego na obrazie Millais’a. Ręce Faltejska lekko unoszą się na wodzie, a stopy są złączone. Cała postać promienieje ogromnym spokojem i lekkością. Otaczają ją lilie wodne, które zagęszczają się w górnej, prawej części zdjęcia, tam też zaczynają się zmieniać barwy - z tych jaśniejszych przechodzą w odcienie ciemniejsze, bardziej złowrogie. Ta część fotografii jest ramą zamykającą przestrzeń od góry. Dół i lewa górna część zdjęcia pozostają otwarte. Całą sylwetkę, odwrotnie niż na wspomnianym obrazie prerafaelity, obserwujemy z lewej strony. W wodzie odbijają się trawy prawdopodobnie porastające brzeg. Kwiaty lilii, znajdujące się w pierwszym planie, również archetypowo łączone są z kobiecością, czystością, niewinnością, macierzyństwem. W kontekście psychoanalitycznym (na przykład zgodnie z teorią Carla Gustava Junga), całe to fotograficzne przedstawienie

12. Zob. http://www.martinfaltejsek.cz/personal/weightless (20.12.2019).

13. Zdeňka Kalnická, Archetyp vody a ženy (Brno: Nakladatelství Emitos, 2007), 109. 
może sugerować chęć powrotu do okresu prenatalnego, dającego poczucie bezpieczeństwa i równowagi, podkreśla potrzebę powrotu do jakiegoś większego uniwersum, którego częścią jest sam przedstawiony na zdjęciu Faltejsek. Na tym przedstawieniu nie widać Szekspirowskiej wierzby, nie ma też opisanego przez pisarza nurtu, w tym wypadku woda jest spokojna, tworzy całość z unoszącą się na niej sylwetką i porastającą jej powierzchnię roślinnością.

Interpretacja motywu Ofelii na fotografii Faltejska znacząco odbiega od pierwowzoru literackiego i malarskiego, jednak pewne elementy jasno na nie wskazują. "[...] Percepcja fotografa wpływa, choć nie musi to być wpływ uświadomiony, na obraz przed wykonaniem fotografii i na proces jego tworzenia. Znaczenia nabiera w tym procesie wybór miejsca, kadru, oświetlenia, czasu ekspozycji, a na końcu - tytułu i sposobu prezentacji, czyli nasycenie obrazu treścią" stwierdza Ewa Hornowska ${ }^{14}$. Takim właśnie nieuświadomionym obrazem jest kompozycja Faltejska, która w swojej warstwie narracyjnej dość jasno nawiązuje do wspomnianych źródeł: literackiego i malarskiego.

Bardziej jednoznaczna jest fotografia kolejnego artysty - Jana Fauknera (1983). Faukner zajmuje się fotografią reklamową i modową, ale również tworzy symboliczne przedstawienia pejzaży czy martwej natury. Szuka, jak sam twierdzi, powiązań pomiędzy realnością a fantazją, naturalnością a sztucznością, oryginałem a imitacją, jednostkowością a globalnością. Ważna jest dla niego estetyka przedstawianych przedmiotów czy postaci; aby były dla niego ciekawe, muszą zawierać w sobie ukryte oznaki piękna, prawdy i głębszych wartości ${ }^{15}$. Cykl Nemesis ${ }^{16}$, do którego należą trzy fotografie, łączy postać kobiety (na każdej fotografii widać inną modelkę, jednak w podobnej pozie). Pierwsza z nich jest silnie inspirowana obrazem Millais’a. Widać na niej kobietę unoszącą się na wodzie. Podobnie jak Ofelia Millais'a i ona ma otwarte oczy, rozchylone usta oraz patrzy przed siebie dość nieobecnym spojrzeniem. Ręce lekko unosi nurt rzeki, a dłonie - tak jak u wspomnianej Ofelii angielskiego malarza - otwierają się w geście dziękczynienia bądź oddania. Liliowa sukienka "wzdęta, niesie ją po wierzchu”. To fotograficzne przedstawienie ma wiele wspólnego również z opisem Szekspira, choć wierzbę, z której spadła bądź skoczyła Ofelia, zastępuje tu kamienna ścieżka prowadząca wprost do wody. Może to być sugestią jednoznacznego odczytania losu Ofelii jako samobójczyni, a nie ofiary nieszczęśliwego wypadku. Postać, podobnie jak na obrazie, ukazana jest $z$ lewej strony, trochę od góry, co sprawia wrażenie, jakbyśmy patrzyli na nią z góry, stojąc na stromym brzegu. Przestrzeń

14. Ewa Hornowska, Urzekająca paralaksa. Fotografia i jej obrazy (Poznań: Muzeum Narodowe, 2015), 26.

15. Zob. http://www.behance.net/janfaukner (20.12.2019).

16. Zob. http://www.janfaukner.com/gallery/personal/nemesis (20.12.2019). 
z każdej strony, poza prawą stroną fotografii, zamykają rośliny porastające brzeg, lecz nieobecne poza nim. Postać kobiety jest spokojna, otwarta, lekko niesiona przez ciemną, mętną wodę. Na dole pośrodku zdjęcia, na tafli widać rozbłyski światła, przypominającego poświatę księżyca. W tym również miejscu ujawnia się pewien dynamizm, ruch wody, reszta fotografii jest raczej statyczna. Ramę fotografii tworzą dwie warstwy - pierwsza to roślinność, następna woda, pośrodku przedstawienia znajduje się ciało dziewczyny. Ciekawego znaczenia nabiera to zdjęcie w powiązaniu z tytułem całego cyklu. Nemesis była bowiem grecką boginią zemsty i sprawiedliwości. Słowo to oznacza również przeznaczenie. Te konotacje łączą się z toposem Ofelii w tragedii Szekspira, przywołują symboliczny kontekst opowieści tekstualnej i jednocześnie łączą się z jej wizualnym odpowiednikiem w postaci obrazu wspominanego już prerafaelity.

U obu czeskich artystów, Faltejska i Fauknera, znakiem narracyjnym, który pozwala włączyć sfotografowane obiekty do pewnego kodu narracji, jest unosząca się na wodzie postać (niekoniecznie kobieca, jak w przypadku fotografii Faltejska). Charakterystyczne ułożenie ciała ujawnia zakodowane kulturowo wzory i nadaje rytm tej fotoopowieści ${ }^{17}$. U obu artystów reinterpretacje bohaterki Szekspira opierają się na współgraniu kontekstów malarskiego i literackiego. Obaj twórcy, choć podobnie, komponują swój przekaz na własnych zasadach artystycznych. Fotografia Martina Faltejska jest przedstawieniem bardziej intymnym, prywatnym, odnoszącym się do jego podświadomości, psychiki. W niej to sam artysta staje się Ofelią, utożsamia się z nią, szuka emocjonalnych podobieństw. U Jana Fauknera przeważa wizja estetyczna, bardziej tajemnicza i ściślej wiążąca się ze swoimi pierwowzorami. Ciemne nasycenie barw może też przywodzić na myśl mistrzów holenderskich. U obu fotografów w centrum zainteresowania znajduje się postać Ofelii i chwila jej śmierci. Inaczej reinterpretuje i ukazuje swoją wizję tej historii kolejna czeska artystka - Barbora Bálková.

\section{Wizualność kontra tekstualność, czyli postmodernistyczny obraz samobójstwa}

"Relacje fotografii i literatury pod koniec XX i na początku XXI wieku to czas hybrydyzacji sztuk, wymagający przyjęcia interdyscyplinarnego oraz interkulturowego kierunku badań” - pisze Marta Koszowy, odwołując się do słów Hansa Beltinga ${ }^{18}$, badaczka stwierdza dalej: “[...] W dokonaniach współczesnych

17. Marianna Michałowska, Foto-teksty. Związki fotografii z narracja (Poznań: Wydawnictwo Naukowe UAM, 2012), 85.

18. Marta Koszowy, "Słowo w kadrze: literatura i fotografia, fotografia i literatura", Rocznik Komparatystyczny nr 5, 2014, 250. 
fotografów słowo wkracza w obręb kadru, zmieniając funkcję i przekaz medium. Tekst stanowi element fotograficznego dzieła lub literacki przypis do rzeczywistości [...]”'19. Taki właśnie literacki przypis do rzeczywistości odnaleźć można w cyklu fotografii zatytułowanym Literary suicides (Samobójstwa w literaturze) autorstwa Barbory Bálkovej.

Barbora Bálková (1978) w swej pracy twórczej lączy klasyczne elementy obrazów, fotografii, rzeźb i instalacji z nowymi mediami. Najczęstszym tematem jej twórczości jest indywidualna tożsamość ludzka, jej doświadczenie i różnorodność. Bálková koncentruje się również na kwestiach społecznych i politycznych dotyczących historii najnowszej odwzorowanej w pamięci indywidualnej i zbiorowej ${ }^{20}$. Na cykl "Literary suicides" składa się sześć fotografii wykonanych w latach 2004-2009, w których artystka wciela się w znane powieściowe samobójczynie. Każde ze zdjęć jest zatytułowane i jasno wskazuje na swoje literackie źródło. A więc mamy tu: Annę Kareninę, Panią Bovary, Kleopatrę, Ofelię, Julię Capuleti i Madame Butterfly. Artystka, opisując ów cykl, stwierdza, że wszystkie te bohaterki literackie wybrały wyjście najprostsze - samobójstwo, jako próbę uwolnienia się od problemów miłosnych ${ }^{21}$. Dalej powołuje się na książkę czeskiego psychologa Josefa Viewegha Sebevražda a literatura (1996, Samobójstwo i literatura), który twierdzi, że czyn samobójczy jest wyrazem skrajnej rozpaczy, ale także miłości własnej i dumy, bowiem jeżeli człowiek nie może być tym, kim chce być, lepiej, aby nie istniał w ogóle. Według psychologa odebranie sobie życia wiąże się też ze środowiskiem społecznym i relacjami interpersonalnymi ${ }^{22}$. Można konstatować, że to społeczeństwo skazało wymienione bohaterki na ten ostateczny czyn odebrania sobie życia. Cykl staje się zatem początkiem dyskusji nad skutkami wyłamywania się z reguł i zasad społecznych, pośrednio wskazując "kulturę jako źródło cierpień".

Bálková każdą z kobiecych bohaterek samobójczyń umieszcza w otoczeniu dziecięcych zabawek, w zaaranżowanej scenerii prywatnego, intymnego świata postaci. Sceneria imituje miejsce ich śmierci, a typowe atrybuty reprezentujące narzędzie zbrodni również należą do świata dziecięcych zabaw i zabawek. Artystka bardziej skupia się na momencie śmierci niż na całościowej estetyce obrazu. W swoim opisie prac wyjaśnia symbolikę tych dziecięcych atrybutów i całego otoczenia. Według niej akt samobójczy, w przypadku tych bohaterek, to przejaw silnej woli życia (każda z nich chciała przecież żyć, ale na własnych warunkach), a jednocześnie staje się też wyrazem ich niedojrzałego charakteru. Osoba dorosła starałaby się bowiem przezwyciężyć wszelkie kryzysy i problemy.

19. Koszowy, Słowo w kadrze..., 252.

20. Zob. http://www.barborabalkova.cz/cv.html (20.12.2019).

21. Zob. http://www.barborabalkova.cz/sebevrazdy.html (20.12.2019).

22. Zob. http://www.barborabalkova.cz/sebevrazdy.html (20.12.2019). 
Kobiety te działały impulsywnie, bezmyślnie, a ich rozpacz przybrała wyraz dziecinnej demonstracji. Cały cykl ma być zatem zachętą do zastanowienia się nad tym, czy nie lepiej stawić czoła nawet najtrudniejszemu problemowi, niż zbyt pochopnie podejmować tak radykalne decyzje $\mathrm{e}^{23}$. Bálková stara się jednak, aby myśl przewodnia całego cyklu nie sugerowała oceny moralnej samego czynu samobójczego. Przywołuje zatem przykłady z przeszłości, kiedy to samobójstwo było ujmowane negatywnie bądź pozytywnie (wspomina akty seppuku i harakiri w Japonii, które były oznaką największej odwagi i szczerości zamiarów, przywołuje poglądy Arystotelesa i Schopenhauera). Infrazę podkreśla również fakt powołania się na inne dzieło literackie, mianowicie na powieść Hermanna Hessego Wilk stepowy. Aby potwierdzić swoje założenie, iż samobójstwa przedstawionych na fotografiach bohaterek literackich zdarzyły się niejako z przypadku, Bálková przywołuje następujące fragmenty powieści niemieckiego pisarza:

[...] niesłusznie zalicza się do samobójców tylko tych, którzy rzeczywiście się zabijają, między nimi jest bowiem wielu takich, którzy są samobójcami jakby z przypadku: odbieranie sobie życia nie jest dla tych ludzi koniecznością. [...] Samobójca [...] niekoniecznie musi pozostawać w szczególnie aktywnym stosunku do śmierci ${ }^{24}$.

Następnie cytuje:

Samobójstwo [...] też ci do niczego nie posłuży, pójdziesz dłuższą i uciążliwszą drogą kształtowania się człowieka, często jeszcze będziesz musiał twą dwoistość zwielokrotnić, a twe skomplikowane życie jeszcze bardziej komplikować $[\ldots]^{25}$.

Powieść Hessego jest więc kolejnym tekstem-kodem będącym inspiracją, ale i infrastyczną emocją wynikającą z jej lektury.

Jedną z fotografii wspomnianego cyklu jest zdjęcie zatytułowane Ofelia. Widzimy na nim młodą kobietę zanurzoną $\mathrm{w}$ dziecięcym, kolorowym dmuchanym basenie. Jej tułów unosi się na płytkiej wodzie, natomiast nogi od kolan w dół są przerzucone przez ściankę basenu. Kobieta ubrana jest w prostą, czarną sukienkę, która, mokra, opina jej ciało. Podobnie jak na obrazie Millais’a, ręce unoszą się na wodzie, a wewnętrzna, otwarta strona dłoni skierowana jest ku górze. W lewej ręce trzyma kwiat hortensji. Oczy otwarte, wpatrzone w przestrzeń, usta lekko rozchylone. Cała postać widziana jest, podobnie jak na obrazie, z prawej strony. Ramą obrazu są tu ściany basenu, których tęczowe kolory zdają się ota-

23. Zob. http://www.barborabalkova.cz/sebevrazdy.html (20.12.2019).

24. Herman Hesse, Wilk stepowy, przeł. Józef Wittlin (Warszawa: Państwowy Instytut Wydawniczy, 1957), 56.

25. Hesse, Wilk stepowy..., 74-75. 
czać topielicę jak aureola. Od góry fotografię zamykają widoczne gęste krzaki. Cała inscenizacja przywodzi na myśl zacisze prywatnego podwórka. Tak, jak w przypadku poprzednich artystów, również na tej fotografii widać dwa kody - literacki i malarski, ale kod malarski, znacząco przekształcony, jest wyrazem indywidualnych przekonań artystki. Nawiązuje ona ponadczasowy dialog z kulturą, z tradycją i moralnością. Doskonale pasują tu słowa Marianny Michałowskiej, która pisze: "[...] fotografia jako przekaz kulturowy nie funkcjonuje samodzielnie lecz zawsze włączona jest w 'kontekst' języka, znaków wizualnych i ich znaczeń [...]”26. Wejście w tekst (na przykład powieści Hessego, tragedii Szekspira oraz pozostałych tekstów literackich, z których artystka zaczerpnęła historie "swoich" bohaterek) prowokuje Bálkovą do wyrażenia tego tekstu w sposób plastyczny, indywidualny, nacechowany stylistyką estetyki postmodernistycznej. Na podstawie słowa, które staje się bodźcem wywołującym w niej przeżycie (a więc ową tytułową infrazą), powstaje praca fotograficzna ${ }^{27}$, cała seria zdjęć odnoszących się do konkretnych dzieł literackich. Bálková tworzy, poprzez ów cykl, swego rodzaju nową mitologię bohaterek, w której przeważającymi elementami są przypadek i oszołomienie.

\section{Podsumowanie}

Celem artykułu była prezentacja kilku przykładów czeskich infraz, a więc artystycznego, w tym wypadku fotograficznego, odzwierciedlenia tekstu literackiego, opisującego śmierć Ofelii - bohaterki tragedii Williama Szekspira Hamlet. Omówione wcześniej fotografie czerpały z dwu źródeł - z tekstu wyjściowego (praźródła), dającego literacki obraz samobójczej śmierci dziewczyny, oraz z jej wizualnego odwzorowania, które stworzył John Everett Millais. W przypadku trzech czeskich artystów odbiorca ma do czynienia $\mathrm{z}$ fotografią aranżowaną, która, jak pisał Roland Barthes, w nieskończoność powiela to, co nastąpiło tylko jeden $\mathrm{raz}^{28}$. Śmierć Ofelii, postaci literackiej, na zawsze zapadła w pamięć tak, jak ją przedstawił Millais, a więc to malarz powołał do życia obraz będący niejako objaśnieniem tekstu Szekspira. Fotografie artystów czeskich dopełniły natomiast i tekst wyjściowy i obraz, powstały w XIX wieku, nowym, współczesnym znaczeniem i kontekstem ${ }^{29}$. Można również stwierdzić, że pewną, nieuświadomioną, strategią artystyczną było zaznaczenie śladu nieobecności, śladu pamięci kulturowej

26. Michałowska, Foto-teksty..., 28.

27. Radziewicz, Od ekfrazy do infrazy..., 172.

28. Roland Barthes, Światło obrazu. Uwagi o fotografii, przeł. Jacek Trznadel (Warszawa: Wydawnictwo Aletheia, 2008), 13.

29. Piotr Zawojski, "Człowiek i aparat. Viléma Flussera filozofia fotografii”, w: Vilém Flusser, Ku filozofi fotografii, przeł. Jacek Maniecki (Warszawa: Wydawnictwo Aletheia, 2015), 22-23. 
metaforycznie czy symbolicznie poświadczającego istnienie tego, co nieobecne i nierzeczywiste. Jak stwierdził Allan Sekula, "[...] fotografia komunikuje poprzez skojarzenie z jakimś ukrytym lub pozostającym w domyśle tekstem. Właśnie ten tekst, lub też system ukrytych wypowiedzi językowych, przenosi fotografię do obszaru czytelności" ${ }^{30}$. W przypadku trzech analizowanych fotografii ich odbiór w dużej mierze zależy od kompetencji kulturowej odbiorcy. Tylko w dziele Bálkovej odbiorca jest informowany wprost, do jakiego źródła odnosi się przedstawiana fotografia. $\mathrm{W}$ pozostałych przypadkach zdjęcia nie mają swoich tytułów, co daje szerokie perspektywy ich odczytania, ale jednocześnie zawęża możliwości interpretacji, jakie daje znajomość owych źródeł. Infraza realizuje się zatem w omówionych fotografiach poprzez koncepcję artystycznego cytatu, który może zostać rozpoznany bądź ukryty.

Na uwagę zasługuje również estetyka przestrzeni wszystkich trzech przedstawień. U Faltejska i Fauknera jest to przestrzeń klasyczna, związana z przyrodą, naturą, natomiast Bálková realizuje swój temat samobójstw literackich poprzez umieszczenie postaci w otoczeniu przedmiotów codziennego użytku, zabawek, a więc stwarza dzięki temu swoistą postmodernistyczną grę z odbiorcą (na przykład umieszczenie na zdjęciach atrybutów śmierci w formie zabawek). Łączy klasyczną poetykę cytowanych powieści z dość teatralnym przedstawieniem konkretnych scen. Można w tym wypadku mówić o pewnym eklektyzmie artystycznym, zabawie pomieszanej z czarnym humorem, co jest cechą charakterystyczną całej twórczości Bálkovej. Ponadto artystka skupia się przede wszystkim na psychologicznym i filozoficznym aspekcie samego aktu samobójstwa, a jej fotograficznie opowiedzianą historię mozna nazwać, za Stanisławem Czekalskim, historią

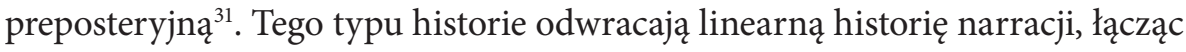
w wizyjny sposób przeszłość z przyszłością, a właściwie sytuując przeszłość i współczesność obok siebie ${ }^{32}$. Inny charakter zdają się mieć fotografie Faltejska i Fauknera. Dla Martina Faltejska fotografia staje się tekstem, który odnosi się do jego prywatnych wspomnień i mikrohistorii osadzonych w pewnej kulturowej przeszłości ${ }^{33}$. Jego fotonarracja jest właśnie relacją owego śladu pamięci, o którym była już mowa, a jednocześnie jest wyrazem najintymniejszego przeżycia. $\mathrm{Z}$ kolei Ofelii z fotografii Fauknera najbliżej jest do estetyki obrazu angielskiego prerafaelity. Faukner bawi się klasyczną konwencją, choć nie w takim stopniu

30. Allan Sekula, Społeczne użycie fotografii, przeł. Krzysztof Pijarski (Warszawa: Wydawnictwo Uniwersytetu Warszawskiego, 2010), 12.

31. Za: Michałowska, Foto-teksty..., 133.

32. Michałowska, Foto-teksty..., 134.

33. Michałowska, Foto-teksty..., 140. 
i nie w taki sposób, jak pozostała dwójka fotografów. Znany szablon pozostaje, artysta zaś uzupełnia go o pewne niuanse romantycznej proweniencji.

Praźródłem wszystkich trzech przedstawień pozostaje jednak, mimo odwołań malarskich, tekst utworu Szekspira. To on buduje sytuację narracyjną omówionych fotografii, a jego znajomość wzbudza w artystach tę infrastyczną emocję wynikającą z jego lektury. W wartwach fotografii osadzona zostaje historia, która, ewoluując i przechodząc przez kolejne filtry kulturowe i artystyczne (malarstwo, wytwory popkultury itd.) otwiera wciąż nowe perspektywy i możliwości odczytania, przez co włącza do gry interpretacyjnej nie tylko artystów, lecz także, a może przede wszystkim, jej odbiorców. 


\section{Bibliografia}

Bálková, Barbora. [CV]. http://www.barborabalkova.cz/cv.html (20.12.2019).

Barthes, Roland. Światło obrazu. Uwagi o fotografii, przeł. Jacek Trznadel. Warszawa: Wydawnictwo Aletheia, 2008.

Cousseau, Anne. 2001. “Ophélie: histoire d'un mythe fin de siècle”. Revue d'histoire littéraire de la France Vol. 101, 1/2001, 101-122. http://www.cairn.info/revue-d-histoire-litteraire-de-la-france-2001-1-page-105.htm (20.12.2019).

Faltejsek, Martin. Weightless. https://www.martinfaltejsek.cz/personal/weightless (20.12.2019).

Faukner, Jan. Nemesis. Jan Faukner Photography. https://www.janfaukner.com/gallery/ personal/nemesis (20.12.2019).

Forstner, Dorothea. Świat symboliki chrześcijańskiej, przeł. Wanda Zakrzewska, Paweł Pachciarek i Ryszard Turzyński. Warszawa: Instytut Wydawniczy Pax, 1990.

Fotocommunity. https://www.fotocommunity.de/photos/ophelia (20.12.2019).

Hesse, Hermann. Wilk stepowy, przeł. Józef Wittlin. Warszawa: Państwowy Instytut Wydawniczy, 1957.

Hornowska, Ewa. Urzekająca paralaksa. Fotografia i jej obrazy. Poznań: Muzeum Narodowe, 2015.

“Jan Faukner". Behance. https://www.behance.net/janfaukner (20.12.2019).

Kalnická, Zdeňka. Archetyp vody a ženy. Brno: Nakladatelství Emitos, 2007.

Koszowy, Marta. "Słowo w kadrze: literatura i fotografia, fotografia i literatura”. Rocznik Komparatystyczny nr 5, 2014, 249-263.

Michałowska, Marianna. Foto-teksty. Związki fotografii z narracją. Poznań: Wydawnictwo Naukowe UAM, 2012.

“Ophelia's Dream”. Stylebubble. https://stylebubble.co.uk/style_bubble/2011/10/ophelias-dream.html (20.12.2019).

Radziewicz, Teresa. "Od ekfrazy do infrazy”. W: Logos - filozofia słowa. Szkice o pograniczach języka, filozofii i literatury, red. Krzysztof Andruczyk, Ewa Gorlewska, Krzysztof Korotkich. Białystok: Instytut Filologii Polskiej, Wydział Filologiczny Uniwersytetu w Białymstoku, 2017. http://repozytorium.uwb.edu.pl/jspui/bitstream/11320/8099/1/T_ Radziewicz_Od_ekfrazy_do_infazy.pdf (20.12.2019).

Sekula, Allan. Społeczne użycie fotografii, przeł. Krzysztof Pijarski. Warszawa: Wydawnictwo Uniwersytetu Warszawskiego, 2010.

Shakespeare, William. Hamlet, przeł. Józef Paszkowski. Warszawa: Państwowy Instytut Wydawniczy, 1973. http://wolnelektury.pl/media/book/pdf/hamlet.pdf (20.12.2019).

“The Name 'Ophelia' - Appropriation \& Commercialization”. https://sites.google.com/ site/opheliaandpopularculture/home/the-name-ophelia-and-its-commercialization (20.12.2019).

Zawojski, Piotr. Człowiek i aparat. Viléma Flussera filozofia fotografii. W: Vilém Flusser, Ku filozofii fotografii, przeł. Jacek Maniecki, 11-35. Warszawa: Wydawnictwo Aletheia, 2015. 